\title{
The role of insulin-like growth factors and epidermal growth factor-related peptides in intraovarian regulation in the pig ovary
}

\author{
J. M. Hammond ${ }^{1}$, S. E. Samaras ${ }^{1}$, R. Grimes ${ }^{1}$, J. Leighton ${ }^{1}$, \\ J. Barber ${ }^{1}$, S. F. Canning ${ }^{1}$ and H. D. Guthrie ${ }^{2}$ \\ 'Department of Medicine, Penn State University, Hershey, PA 17033, USA; and ' USDA/ARS, \\ Beltsville Agricultural Research Center, Beltsville, MD 20705, USA
}

The autocrine and paracrine role of the insulin-like growth factors (IGFs) and epidermal growth factor (EGF)-related peptides in pig ovary are reviewed. For convenience, each of these regulatory systems is divided into several interactive components: regulated expression of the growth factors, growth factor reception at the cell surface and intracellular action of the growth factors. In addition, the concept of regulated bioavailability and targeting of growth factors in the extracellular space is developed as an important control locus and area for future study. With regard to the IGF system, these components include two ligands - IGF-I and -II, both expressed in the porcine ovary - and the possibility of three receptors. IGF-I and the type I IGF receptor appear to be the most important in stimulating ovarian function and amplifying hormone action. In addition, the 'set-point' of the ovarian IGF system may be determined by the activity of several IGF-binding proteins (IGFBPs). At least four of these proteins are expressed in the pig ovary. Studies of their regulation and action in ovarian cells indicate that they can function as antagonists to FSH and the IGFs. However, preliminary evidence suggests a more dynamic model in which these proteins may direct the site and timing of IGF effects. There are fewer data on the EGF system. At least four EGF-related peptides are expressed in pig ovaries, but insufficient information is available to predict their physiological regulation. These peptides are potent mitogens for ovarian cells. Their steroidogenic effects are more variable, apparently depending on the level of differentiation of target cells as well as the presence or absence of critical co-factors. Differential targeting and activation of these peptides can be predicted from their primary structure. However, few data are yet available to substantiate these mechanisms in the ovary. The data in each of these areas suggest a pivotal role for these systems in ovarian function. However, control of these systems in vivo will be required to confirm this hypothesis.

\section{Introduction/Historical Overview}

The need to invoke intraovarian regulatory principles has been obvious for several decades and derives mainly from the selectivity of ovarian growth and differentiation during the reproductive cycle. Steroid hormones were early candidates for this regulation and are now generally accepted as important intraovarian regulators. However, in this review, attention will be directed toward the regulatory peptides that have been implicated in these processes. Initial efforts to define such peptide regulators emphasized 
in vitro bioassays which were assumed to reflect intraovarian autocrine and paracrine relationships. Such studies defined a number of useful physiological constructs such as oocyte maturation inhibitor, luteinization inhibitors, and antagonists to gonadotrophin action (reviews in Channing and Segal, 1982; Hammond, 1981). However, biochemical evidence for such proteins remains inconclusive despite considerable work. In the latter half of the 1980s, the emphasis on intraovarian regulation shifted toward growth factors, which, for the most part, had been defined and isolated in other tissues. Progress in this field, reviewed below, has led to the working hypothesis that most and perhaps all of the previously described concepts could be accounted for by defined growth factors and other cytokines which are now known to be secreted and active in ovarian cells. A list of such factors would include the insulin-like growth factors, the epidermal growth factor-like family, fibroblast growth factors, transforming growth factor- $\beta$ and its subtypes, and several cytokines which have been more classically implicated in macrophage and haematopoietic regulation, but which have potent effects on ovarian cells (Hammond et al., 1988b; Adashi, 1992). This will be a selective review emphasizing data collected in porcine ovarian systems and that derived from our own laboratory in particular. These data concern the ovarian IGF system and the epidermal growth factor-related peptides. New data on these growth factors suggest reconsideration of their function. In addition, these two growth factor families are among the most intensely investigated of the autocrine/paracrine systems in the ovary, and provide convenient examples of the current state-of-the-art in the field, the techniques that can be brought to bear on such physiological questions, and the additional evidence that will be required to establish their role definitively.

The classical components of these systems include the ligands or growth factors themselves, their receptors and an intracellular signal transduction pathway controlling either cell replication or steroidogenic differentiation of ovarian cells. In the last few years, it has become clear that this framework omits a significant point for regulation of these systems. This step determines growth factor bioavailability, targeting and activation - processes that seem crucial to the operation of autocrine and paracrine mechanisms (Flaumenhaft and Rifkin, 1992; Logan and Hill, 1992). Data accumulated through investigations of each of these components have resulted in a relatively comprehensive picture of the ovarian IGF system. Data on the EGF family of peptides is less complete, but recent studies suggest that a better understanding will soon be obtained.

\section{Expression of the IGFs and EGF-related Peptides in Pig Ovary}

\section{IGF expression}

The ability of pig ovarian cells to secrete IGFs has been surmised from studies measuring such factors in ovarian follicular fluid, ovarian cell conditioned media, and by analysis of the expression of mRNA for such peptides. Our laboratory has focused on this area in particular and our results have been recently reinforced and extended by others.

IGFs can easily be measured in pig follicular fluid (Hammond et al., 1982, 1985). IGF-I and -II are both present (Hammond et al., 1985; Spicer et al., 1992; Samaras et al., 1993b). The concentration of IGF-I increases in follicular fluid during spontaneous follicular development (Hammond et al., 1985) and after treatment by gonadotrophins (Hammond et al., 1988a) and growth hormone (Bryan et al., 1989; Hammond et al., 1993b). Related data have been developed recently by Howard and Ford (1992), who studied follicles of sows during follicular development after weaning; they failed to show clear relationships between concentrations of IGF-l and follicular size. However, there were higher concentrations in the growing follicles before the LH surge. In our studies, IGF-II concentrations were not increased by gonadotrophin or growth hormone administration and, in fact, showed a slight decline (Samaras et al., 1993b).

To establish the location of IGF-I expression in vivo, we used in situ hybridization (Hammond et al., 1993 b), which showed that IGF-I is expressed predominantly in the membrana granulosa of medium size follicles and, to a lesser extent, in functioning corpora lutea (Fig. 1). These studies indicated that the expression of IGF-I in ovarian follicles in vivo was quite variable with some follicles being virtually devoid of mRNA. In an attempt to relate the expression of IGF-I more clearly to recognized parameters of ovarian follicular development, we examined a well-characterized collection of ovarian follicles during the 
period of synchronized follicular growth triggered by progestin withdrawal (Samaras et al., 1993a). These studies showed statistically significant correlations of IGF-I with days of the follicular phase, follicular size, and oestradiol concentration. In this model, IGF-I expression reached peak values on day 5 after altrenogest withdrawal and then declined (after the LH surge) on day 7. Collectively, these data indicate that IGF-I is expressed in the pig ovary and regulated in a physiologically meaningful fashion. These studies are consistent with the notion that IGF-I may be involved in, or at least linked to, the process of follicular growth and selection. Although IGF-II peptide and mRNA (Hammond et al., 1993b) can also be readily detected, we did not find a relationship of this peptide to hormone action or follicle development. There is less mRNA for IGF-I in the porcine corpus luteum than in the follicle. However, mRNA for IGF-I can easily be detected in the corpus luteum; our initial studies suggest that the peptide is expressed in both large and small luteal cells (J. Gadsby, J. Lovdal, J. Barber and J. M. Hammond, unpublished).

(a)

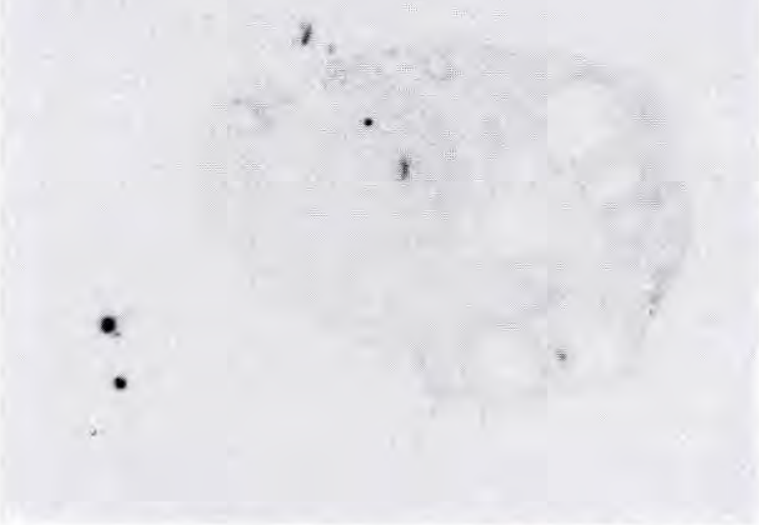

(b)

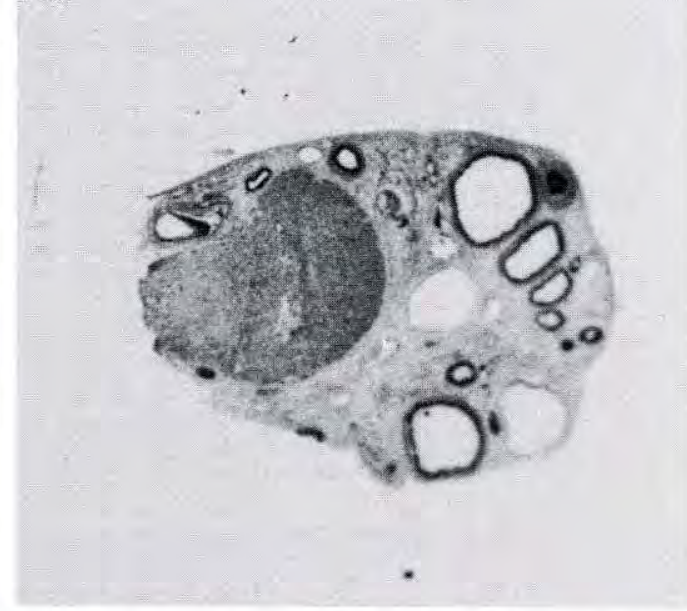

Fig. 1. Expression of insulin-like growth factor I (IGF-I) in luteal phase porcine ovary. (a) Control RNA probe; (b) antisense probe. Reproduced from Hammond et al. (1993b) with permission.

Evidence concerning the secretion of IGF-I by porcine ovarian cells and its hormonal regulation has been provided directly by studies with cultured pig granulosa cells. Cells from 1-3 mm follicles of immature gilts secrete IGF-I in serum-free cultures for 7-10 days and respond to treatment with FSH, oestradiol, LH and growth hormone (Hsu and Hammond, 1987a,b) and EGF (Mondschein and Hammond, 1988). Recently, Hatey et al. (1992) found that granulosa cells from medium sized $(3-5 \mathrm{~mm})$ follicles expressed IGF-I mRNA in culture and that the amount of mRNA was increased by gonadotrophic hormones. We have recently shown a threefold increase in steady-state IGF-I mRNA with forskolin as a cAMP inducer (S. Samaras, unpublished). Since IGF-I has been shown to increase the steroidogenic effectiveness of gonadotrophins and cAMP (see below), these data suggest that IGF-I can serve as an autocrine amplifier of gonadotrophin action in cells or follicles that develop the ability to express this peptide. This possibility was directly tested with antibodies that bind IGF-I (Mondschein et al., 1989) and these antibodies caused a 50\% reduction in $\mathrm{FSH}$-dependent steroidogenesis.

\section{Expression of EGF-like peptides in the porcine ovary}

There are relatively few data on the expression of EGF-like peptides in the porcine ovary. However, these studies reflect substantial current interest in this problem. Several years ago, we found that the concentrations of receptor-active EGF-like peptides in pig follicular fluid were substantially higher than in pig plasma (Hsu et al., 1987) and that this activity declined in the preovulatory follicle. On the basis of these data and complementary studies in rodents (Kudlow et al., 1987) and cows (Skinner et al., 1987), we 
predicted (Hammond et al., 1988b) that the ovarian EGF-like peptide in this species would be TGF- $\alpha$, that it would be of thecal origin, and that it would be highest in immature follicles; i.e. regulated in a fashion opposite to that of IGF-I. In recent months, we have continued our studies with refined assays for TGF- $\alpha$ mRNA and peptide (Hammond et al., 1993a). Surprisingly, the granulosa cells seem enriched in this mRNA compared with theca, and the peptide and mRNA can be induced by forskolin treatment in granulosa cell culture; that is with increased differentiation of these cells. Our studies also showed relatively abundant TGF- $\alpha$ mRNA in the pig corpus luteum. Kennedy et al. (1993) showed that each of the four currently defined members of the EGF family of growth factors - TGF- $\alpha$, EGF, heparin binding EGFlike growth factor and amphiregulin - are expressed in the pig corpus luteum. These data add additional complexity and interest to defining the role of such growth factors in the pig ovary. It now seems possible that each of these peptides may be expressed differentially and subserve a discrete physiological role. Each of these molecules would be predicted to bind to the same receptor and stimulate similar intracellular events; however, they may undergo quite disparate processing and targeting events as discussed in the next section. For this family of growth factors, as for the IGFs, such events may be critical in determining their site and time of action.

\section{Regulation of the Bioavailability of Ovarian Growth Factors}

\section{The role of ovarian IGF binding proteins (IGFBPS)}

Since our early studies of IGF concentrations in ovarian follicular fluid and granulosa cell conditioned medium (Hammond et al., 1982, 1985), it has been clear that high molecular weight molecules that bind IGF tracer are present in ovarian samples along with the IGF ligands. In the last few years, there has been much interest in this area, which has led to the purification, cloning and sequencing of six discrete gene products which share the property of high-affinity binding of IGF-I and -II but have variable tissue and hormone-dependent expression (reviewed in Rechler, 1993). Pig follicular fluid has been shown to be a rich source of such proteins and many of the known IGFBPs were isolated from this source (Shimasaki and Ling, 1991). Using ligand blotting in which the IGFBPs are resolved in gel electrophoresis and measured by their ability to bind ${ }^{125}$ I-labelled IGF-II, coupled with immunoblotting and immunoprecipitation, we have identified IGFBP-2 to -5 in samples of ovarian follicular fluid and granulosa cell conditioned medium. The expression and identification of these peptides has been confirmed by northern analysis with appropriate cDNA probes (Mondschein et al., 1990, 1991; Grimes and Hammond, 1992; Grimes et al., 1992, 1993a). The most abundant of these proteins in follicular fluid and granulosa cell conditioned medium is IGFBP-3. The concentrations of this peptide are comparatively invariant during the growth of the ovarian follicle (Mondschein et al., 1991); in contrast, concentrations of the smaller molecular size IGFBPs $(-2,-4$ and -5$)$ appear to decline with follicular growth and development. Howard and Ford (1992) have supported an inverse relationship between the concentrations of these low molecular weight forms and follicular growth and development. In particular, these studies indicated an inverse relationship between concentrations of IGFBP-2 and follicular concentrations of oestrogen. Amounts of IGFBP-2 mRNA in individual pig follicles during follicular growth (in progestin-synchronized gilts) show a striking inverse relationship to days of the follicular phase, oestradiol concentrations and follicular size (Samaras et al., 1993a). IGFBP-4 and -5 were also found to be inversely related to follicular development; however, the relationship was more complex with an apparent increase in the expression of these peptides in some preovulatory follicles (Hammond et al., 1992a). None the less, the available data in pig follicular fluid indicate a relatively striking inverse relationship between the expression of low molecular weight IGFBPs $(-2,-4$ and -5$)$ and follicular growth and development. This relationship suggests a possible role for these proteins in inhibiting these processes (or in selecting follicles for atresia). The possibility of this relationship is supported by our studies (Samaras and Hammond, unpublished) in which an inhibitory action of IGFBP-3 on gonadotrophin action in porcine ovarian cells has been demonstrated. These results are similar to our previous studies with an antibody to IGF-I, and consistent with the hypothesis that the effects of IGFBPs derive from their ability to sequester locally secreted IGF-I and neutralize its stimulatory effects.

Additional understanding of the physiological regulation of IGFBPs has come from detailed studies of the secretion of these factors by cultured granulosa cells. In these systems, the concentrations of IGFBP-2, -3 , and particularly -5 , have been shown to be stimulated by treatment with IGF-I (Grimes and Hammond 
1992). In contrast, gonadotrophins and cAMP generally inhibit these binding proteins (Mondschein et al., 1990; Grimes et al., 1992). However, concentrations of IGFBP-4 are increased at submaximal concentrations of gonadotrophins, and IGF-I treatment has insignificant effects (Grimes et al., 1993a). Interestingly, $\mathrm{PGE}_{2}$ inhibits while $\mathrm{PGF}_{2 \alpha}$ stimulates expression of IGFBP-3 in cultures of partially luteinized granulosa cells (Grimes et al., 1993b), suggesting that the expression of this protein could be involved in the antagonisticluteotrophic and luteolytic effects of these hormones. Collectively, these data support the notion that the IGFs and their binding proteins function antagonistically in the regulation of the growth of the ovarian follicle and maintenance of the corpus luteum in pigs. This concept is supported by the inhibitory action of exogenous IGFBPs on ovarian cellular function and by the opposing effects of gonadotrophins and follicular growth on the secretion of the IGFBPs versus IGF-I and steroids. However, this concept fails to account for the complexity of the system, including the divergent expression of the several members of the IGFBP family and stimulatory actions of the proteins in other systems (Clemmons, 1991). Undoubtedly a more complex relationship between the expression of the IGFs the IGFBPs, and the presentation of the IGFs to their receptors on ovarian target cells will eventually be developed.

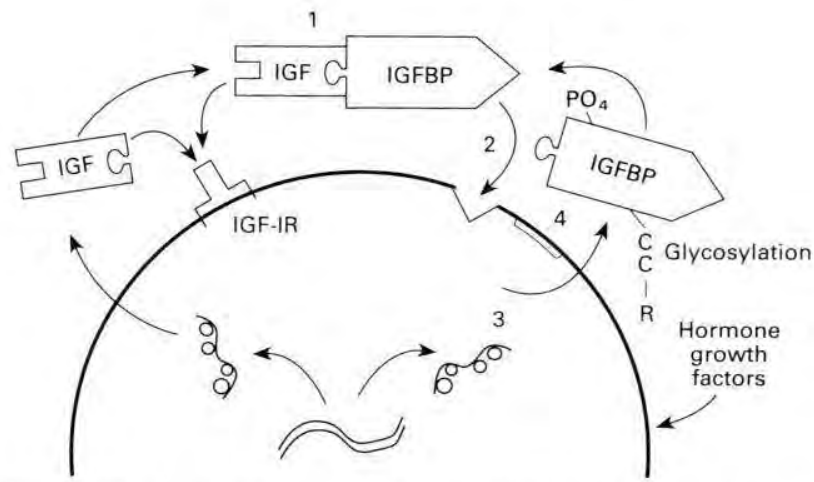

Fig. 2. The insulin-like growth factor I (IGF-I) autocrine system in porcine granulosa cells. Several aspects of this system are illustrated, including IGF-I biosynthesis and action through the IGF-I receptor. Points of emphasis relate to extracellular processing and targeting of IGF-I through the IGF binding proteins (IGFBPs). (1) IGF-IGFBP complex in the extracellular space; (2) binding site for IGFBP on cell surface or extracellular matrix; (3) post-translational modification of IGFBPs; (4) putative cellular processing site for IGFBPs, for example proteolytic enzyme, phosphatase.

A working model of the possible role of IGFBPs in targeting the actions of IGFs is shown (Fig. 2). Central to this model is the existence of an extracellular pool of IGFs complexed to the IGFBPs, which serves as a reservoir of potentially active IGFs. With processing of the complex, the IGFs can be presented to receptors on target cells. This model has not been fully substantiated in any system, but data for the existence of activity at each of the control loci depicted have been developed in one or more systems (Clemmons, 1991; Rechler, 1993): these include binding of the IGFBPs to attachment sites on the cell glycocalyx (integrins or related attachment sites) or to mucopolysaccharides in the extracellular matrix; post-translational modification of the IGFBPs by phosphorylation, glycosylation or proteolytic processing could modify the affinity of these proteins for the IGFs and, hence, delivery of the IGFs to the receptors. Our own studies (Grimes and Hammond, in press) suggest that IGFBP-3 is proteolytically processed by porcine granulosa cells, probably by a serine protease, and that this action is inhibited by IGF-I. Similar effects can also be shown for IGFBP-5 (Fig. 3) for which a striking induction of IGFBP-5 by IGF-I is associated with a diminution in its low molecular weight processing variant. Further studies of this sort as well as of the critical steps in interaction of IGF-I-IGFBP complexes at the cell surface need to be performed before the full importance of these mechanisms can be understood. Current data suggest that these effects may be important in controlling the overall set point of the ovarian IGF system. 


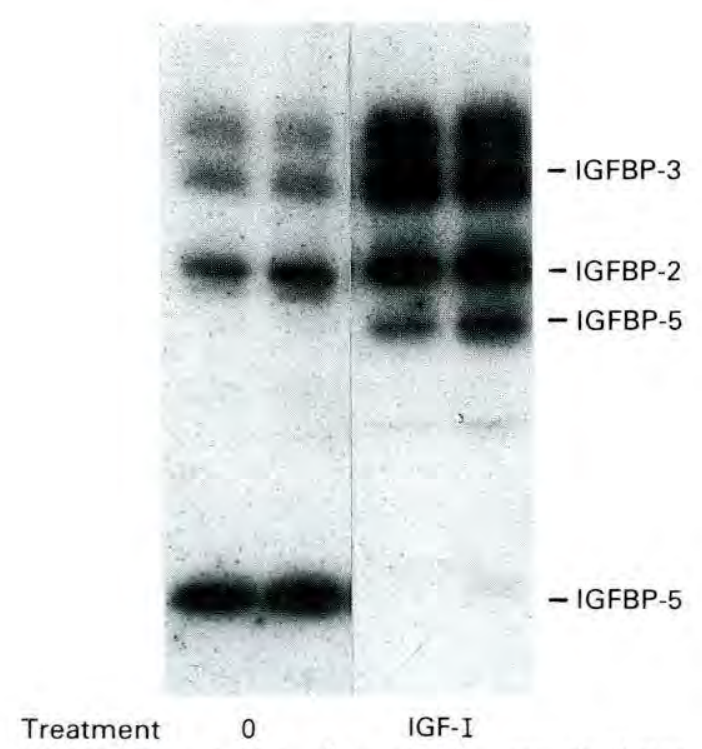

Fig. 3. Ligand blot of insulin-like growth factor binding protein (IGFBP) activity in pig granulosa cells cultured with and without IGF-I.

\section{Bioavailability and targeting of EGF-like peptides}

Little or no information is available regarding post-translational processing of the EGF-like peptides in the pig ovary. It is not known why the pig ovary expresses four discrete growth factors which apparently bind to the same receptor, but the answer may require a better understanding of differential processing and targeting of these peptides within the ovary. Data from other systems suggest that these processes occur and are potential sites for regulation. For example, EGF and TGF- $\alpha$ are often secreted as a large precursor that spans the membrane of the secretory cell and requires proteolytic cleavage to be released into the extracellular space (Prigent and Lemoine, 1992). Site-directed mutagenesis of this cleavage site has shown that TGF- $\alpha$ can be active without full secretion, but the targeting of such actions may be restricted to the cell of origin and immediately adjacent cells (Lee, 1991). It is also possible that there are targeting mechanisms for heparin binding EGF-like peptide based on the demonstrated attachment of this molecule to mucopolysaccharides similar to the extracellular matrix. This peptide could then be released proteolytically or displaced by sulfated molecules in steps parallel to those outlined in our model for the IGFs (Fig. 2). Such mechanisms occur for many if not most growth factor-based autocrine and paracrine systems (reviewed in Logan and Hill, 1992; Flaumenhaft and Rifkin, 1992).

\section{Cellular Actions of Ovarian Growth Factors}

\section{Actions of the IGFs}

The actions of the IGFs on the pig ovary have now been studied for more than 10 years and have been extensively reviewed in other publications (Hammond et al., 1988b, 1991; Giudice, 1992) and are therefore not discussed in detail here. The action of the IGFs in the ovary, as in other tissues, depends on binding to cell surface receptors, activation of receptor autophosphorylation and stimulation of a subsequent cascade of intracellular phosphorylation steps, which activate transport mechanisms, cell growth and differentiated function. In the pig ovary, most of the actions of the IGFs are probably mediated through the type-I IGF receptor, although there is also evidence for insulin receptors and type-II IGF (mannose-6-phosphate) receptors. The steps between receptor activation and stimulation of cellular processes seem similar to those for insulin, which are being worked out in increasing detail in other 
systems (for review, see Kahn et al., 1993). The preliminary data suggest that a similar phosphorylation cascade operates in the bovine ovary (Chakravorty et al., 1992), and that related processes occur in the pig ovary (Romero et al.; 1993). More detailed information is available concerning the effects of the IGFs on cell specific end points; and these can be divided into growth or differentiative pathways which predominate depending on the presence or absence of other extracellular stimulators and on the level of differentiation of the ovarian cell. Although IGF-I is a mitogen for ovarian cells, it is not particularly potent when used alone. However, in the presence of EGF or related peptides, it causes a synergism in DNA synthesis and cell replication (Hammond and English, 1987; May et al., 1988). In the presence of gonadotrophins, the steroidogenic or differentiative actions of the IGFs predominate. IGF-I has the potential for synergizing with the gonadotrophins at several points in the steroidogenic pathway (see Giudice, 1992, for review). These interactions, coupled with the previously described effects of gonadotrophins to increase IGF-I secretion and decrease inhibitory IGFBPs represent an integrated, mutually facilitatory set of mechanisms whereby gonadotrophin effects may be amplified through the ovarian IGF system.

\section{Actions of EGF-like peptides on ovarian cells}

Like other peptide growth factors, EGF actions are mediated through cell surface receptors with tyrosine kinase activity followed by an intracellular phosphorylation cascade activating genomic events. EGF is probably the most active mitogenic peptide for pig granulosa cells (Hammond and English, 1987; May et al., 1988). Hammond et al. (1988b) summarized the effects of EGF on pig ovarian cells as stimulating replication while restraining differentiation. Mondschein and Hammond (1988), Gangrade et al. (1991) and May et al. (1987) have indicated that this represented a substantial oversimplification. In contrast to the IGFs, which function as global stimulators of ovarian function, the EGF-like peptides can have opposite effects on the same endpoints including progesterone secretion, aromatase and FSHbinding depending on the species, level of differentiation and culture conditions (including the presence or absence of other growth factors) under which ovarian cells are examined in vitro. The physiological and biochemical basis for these findings are unknown.

\section{Conclusions}

From the foregoing discussion a case can be made for a pivotal role for IGFs and EGF-like peptides in the growth and development of the pig ovary. The level of understanding of the several components of these systems is becoming increasingly detailed. However, studies to date have relied heavily on in vitro techniques. It will be necessary to gain control over ovarian growth factors in vivo to confirm the growth factor hypothesis and to manipulate such systems to our advantage. Studies to date that bear on this question include hormonal manipulation of the ICF system in the ovary (and throughout the body) by the administration of growth hormone. In women, considerable success has been reported in achieving an increase in gonadotrophin sensitivity (reviewed in Giudice, 1992) as predicted by the in vitro results reviewed above. However, comparable studies in pigs (Bryan et al., 1989; Guthrie et al., 1992; Spicer et al., 1992) do not clearly demonstrate the predicted increase in ovarian development and gonadotrophin responsivity. In fact, these studies suggest an inhibition of several critical aspects of ovarian function (despite a dramatic increase in ovarian IGF-I concentrations). These data indicate that intraovarian IGF-I cannot be viewed as the final common pathway for ovarian cellular growth and differentiation. Critical timing of activation of the IGF system and the presence or absence of other supportive hormonal and intraovarian factors, for example gonadotrophins and IGFBPs, may be crucial.

In theory, ovarian growth factors could also be modulated by genetic manipulation of growth factor expression. A number of laboratories have now begun 'knock out' experiments to disrupt growth factor gene function systematically in transgenic mice. The IGF-Il gene has been disrupted by these techniques with modest effects (if any) on reproductive function in the preliminary analysis which has been performed (DeChiara et al., 1991). Once again, these studies indicate that the IGF system may not be the final common pathway for ovarian function, but a facilitatory mechanism. In addition, it seems likely that the body has compensatory mechanisms to avoid potentially lethal mutations in critical gene families. In the 
IGF system, in particular, this is manifest by a multiplicity of ligands and receptors that have discrete but overlapping functions. In the EGF family of peptides, the overlap in ligands is even greater. An ideal experiment might entail transgenic animals with growth factor genes driven by ovary-specific, hormoneresponsive promoters, for example FSH receptor or aromatase. To our knowledge, such experiments have not been completed in any species.

\section{References}

Adashi EY (1992) The potential relevance of cytokines to ovarian physiology. Joumal of Steroid Biochemistry and Molecular Biology 43 439-444

Bryan KA, Hammond JM, Canning S, Mondschein JS, Carbaugh F, Clark AM and Hagen DR (1989) Reproductive and growth responses of gilts to exogenous porcine pituitary growth hormone Joumal of Animal Science 67 196-205

Chakravorty A, Joslyn $M$ and Davis IS (1992) Synergistic interactions among the adenylate cyclase (LH/CAMP) and tyrosine kinase (insulin/IGF-I) systems in bovine luteal cells Biology of Reproduction 46 Supplement 192 (Abstract)

Channing CP and Segal S) (Eds) (1982) intraovarian Control Mechanisms (Proceedings of a Conference on Intraovarian Control Mechanisms, Bellagio, Italy), pp 1-392. Plenum Press, New York

Clemmons DR (1991) Insulin-like growth factor binding proteins: roles in regulating IGF physiology fournal of Developmental Physiology 15 105-110

DeChiara TM, Robertson EJ and Efstratiadis A (1991) Parental imprinting of the mouse insulin-like growth factor II gene Cell 64 849-859

Flaumenhaft $R$ and Rifkin DB (1992) The extracellular regulation of growth factor action Molecular Biology of Cell 3 1057-1065

Gangrade BK, Davis JS and May JV (1991) A novel mechanism for the induction of aromatase in ovarian cells in vitro: role of transforming growth factor alpha-induced protein tyrosine kinase Endocrinology 129 2790-2792

Giudice LC (1992) Insulin-like growth factors and ovarian follicular development Endocrine Reviews $13641-669$

Grimes RW and Hammond JM (1992) Insulin and insulin-like growth factors (IGFs) stimulate production of ICF-binding proteins by ovarian-granulosa cells Endocrinology 131 553-558

Grimes RW and Hammond JM Proteolytic degradation of insulin-like growth factor binding protein-3 by porcine ovarian granulosa cells in culture: regulation by IGF-I Endocrinology (in press)

Grimes RW, Samaras SE. Barber JA, Shimasaki S, Ling N and Hammond JM (1992) Gonadotropin and CAMP modulation of IGF binding protein production in ovarian-granulosa cells American Joumal of Physiology 262 E497-E503

Grimes RW. Barber JA, Shimasaki S, Ling N and Hammond JM (1993a) Porcine ovarian granulosa cells secrete insulin-like growth factor (IGF)-binding proteins-4 and -5 and express their mRNAs: regulation by FSH and IGF-1 Biology of Reproduction (in press)

Grimes RW, Samaras SE and Hammond JM (1993b) Divergent actions of prostaglandins $-E_{2}$ and $-F_{2 a}$ on the regulation of insulin-like growth factor-binding protein-3 in luteinized granulosa cells Endocrinology 132 14 14-1416

Guthrie HD, Pursel VG, Bolt DJ, Cooper BS, Palmiter RD and Brinster RL (1992) Inhibitory effects of bovine growth hormone gene expression on PMSG-induced follicle matu- ration in transgenic prepubertal gilts Biology of Reproduction 46 Supplement 1105 (Abstract)

Hammond JM (1981) Peptide regulators in the ovarian follicle Australian fountal of Biological Science 34 491-504

Hammond JM and English HF (1987) Regulation of DNA synthesis in cultured porcine granulosa cells by growth factors and hormones Endocrinology 120 1039-1046

Hammond JM. Veldhuis JD, Seal TW and Rechler MM (1982) Intraovarian regulation of granulosa-cell replication. In Intraovarian Control Mechanisms, pP 341-356 Eds CP Channing and SI Segal. Plenum Press, New York

Hammond JM, Baranao JLS, Skaleris D, Knight AB, Romanus JA and Rechler MM (1985) Production of insulin-like growth factors by ovarian granulosa cells Endocrinology 117 2553-2555

Hammond JM, Hsu C-J, Klindt J, Tsang BK and Downey BR (1988a) Gonadotropins increase concentrations of immunoreactive insulin-like growth factor-I in porcine follicular fluid in vioo Biology of Reproduction 38 304-308

Hammond JM, Hsu C-J, Mondschein JS and Canning SF (1988b) Paracrine and autocrine functions of growth factors in the ovarian follicle Jounal of Animal Science 66 21-31

Hammond JM. Mondschein JS. Samaras SE, Smith SA and Hagen DR (1991) The ovarian insulin-like growth factor system Jounal of Reproduction and Fertility Supplement $\mathbf{4 3}$ 199-208

Hammond JM, Barber JA, Canning SF and Guthrie HD (1992a) Expression of insulin-like growth factor binding proteins-4 and $\mathbf{- 5}$ during the growth of porcine ovarian follicles Biology of Reproduction 46 (Supplement 1) 85 (Abstract)

Hammond JM, Barber JA, Canning SF and Hagen DR (1992b) Expression of insulin-like growth factor binding proteins in the porcine ovary; localization and regulation Proceedings of the 74ih Annual Meeting of the Endocrine Sociely 238 (Abstract)

Hammond JM, Barber JA and Samaras SE (1993a) Expression of transforming growth factor- $\alpha$ (TGF- $\alpha$ ) by porcine ovarian cells in vivo and in vitro Biology of Reproduction 48 Supplement 1 in press (Abstract)

Hammond JM, Samsaras SE, Grimes RW, Leighton JK and Guthrie HD (1993b) The role of insulin-like growth factors and their binding proteins in the development of the porcine ovarian follicle. In Progress in Endocrinology (the Proceedings of the Ninth International Congress of Endocrinology, Nice, 1992) Eds R Momex, C Jaffiol and J Leclere. Parthenon Publishing Group, Lancs (in press)

Hatey F, Langlois I, Mulsant P, Bonnet A. Benne F and Gasser F (1992) Gonadotropins induce accumulation of insulin-like growth factor I mRNA in pig granulosa cells in vitro Molecular and Cellular Endocrinology 86 205-211

Howard HJ and Ford JJ (1992) Relationships among concentrations of steroids, inhibin, insulin-like growth factor-I (ICF-I), and IGF-binding proteins during follicular development in weaned sows Biology of Reproduction 47 193-201 
Hsu C-J and Hammond JM (1987a) Gonadotropins and estradiol stimulate immunoreactive insulin-like growth factor-I production by porcine granulosa cells in vitro Endocrinology 120 198-207

Hsu C-J and Hammond JM (1987b) Concomitant effects of growth homone on secretion of insulin-like growth factor1 and progesterone by cultured porcine granulosa cells Endocrintology 121 1343-1348

Hsu C-J, Holmes SD and Hammond JM (1987) Ovarian epidermal growth factor-like activity: concentrations in porcine follicular fluid during follicular enlargement Biochemical and Biophysical Research Communications 147 242-247

Kahn CR, White MF and Shoelson SE (1993) The insulin receptor and its substrate: molecular determinants of early events in insulin action. In Recent Progress in Hormone Research 48 291-340 Ed. CW Bardin. Academic Press, Inc., San Diego

Kennedy TC, Brown KD and Vaughan TJ (1993) Expression of the genes for the epidermal growth factor receptor and its ligands in porcine corpora lutea Endocrinology 132 1857-1859

Kudlow JE, Kobrin MS, Purchio AF, Twardzik DR, Hemandez ER, Asa SL and Adashi EY (1987) Ovarian transforming growth factor-a gene expression: immunohistochemical localization to the theca-interstitial cells Endocrinology 121 1577-1579

Lee DC (1991) Transforming growth factor a: expression and biological activities of the secreted and integral membrane forms. In Growth Factors in Reproduction, pp 39-51 Ed. DW Schomberg. Springer-Verlag, New York

Logan A and Hill DJ (1992) Bioavailability: Is this a key event in regulating the actions of peptide growth factors? joumal of Endocrinology 134 157-161

May JV, Buck PA and Schomberg DW (1987) Epidermal growth factor enhances ['29]|iodo-follicle-stimulating hormone binding by cultured porcine granulosa cells Endocrinology 120 2413-2420

May JV, Frost JP and Schomberg DW (1988) Differential effects of epidermal growth factor, somatomedin-C/insulin-like growth factor I, and transforming growth factor-beta on porcine granulosa cell deoxyribonucleic acid synthesis and cell proliferation Endocrinology 123 168-179

Mondschein JS and Hammond JM (1988) Growth factors regulate immunoreactive insulin-like growth factor-I production by cultured porcine granulosa cells Endocrinology 123 463-468

Mondschein JS, Canning SF, Miller DO and Hammond JM (1989) Insulin-like growth factors (IGFs) as autocrine/paracrine regulators of granulosa cell differentiation and growth: studies with a neutralizing monoclonal antibody to IGF-I Biology of Reproduction 40 79-85

Mondschein JS, Smith SA and Hammond JM (1990) Production of insulin-like growth factor binding proteins (ICFBPs) by porcine granulosa cells: identification of IGFBP-2 and -3 and regulation by hormones and growth factors Endocrinology 127 2298-2307

Mondschein JS, Etherton TD and Hammond JM (1991) Characterization of insulin-like growth factor-binding proteins of porcine ovarian follicular fluid Biology of Reproduction 44 $315-320$

Prigent SA and Lemoine NR (1992) The type I (EGFR-related) family of growth factor receptors and their ligands Progress in Growth Factor Research 4 1-24

Rechler MM (1993) Insulin-like growth factor binding proteins Vitamins and Homones 47 1-114

Romero G, Garmey JC and Veldhuis JD (1993) The involvement of inositol phosphoglycan mediators in the modulation of steroidogenesis by insulin and insulin-like growth factor-l Endocrinology 132 1561-1568

Samaras SE, Hagen DR, Shimasaki S, Ling $N$ and Hammond JM (I992) Expression of insulin-like growth factor binding protein (IGFBP) -2 and -3 mRNA in the porcine ovary: localization and physiological changes Endocrinology 130 2739-2744

Samaras S, Guthrie D, Barber J and Hammond JM (1993a) Expression of the mRNAs for the insulin-like growth factors and their binding proteins in individual porcine ovarian follicles Endocrinology (in press)

Samaras SE, Hagen DR, Bryan KA, Mondschein JS, Canning SF and Hammond JM (1993b) Effects of growth hormone and gonadotropin on the insulin-like growth factor system in the porcine ovary Biology of Reproduction (in press)

Shimasaki S and Ling N (1991) Identification and molecular characterization of insulin-like growth factor binding proteins (IGFBP-1, -2, -3, -4, -5 and -6) Progress in Growth Factor Research 3 243-266

Skinner MK, Lobb D and Dorrington JH (1987) Ovarian thecal/ interstitial cells produce an epidermal growth factor-like substance Endocrinology 121 1892-1899

Spicer LJ, Klindt J, Buonomo FC, Maurer R., Yen JT and Echternkamp SE (1992) Effect of porcine somatotropin on number of granulosa cell luteinizing hormone/human chorionic gonadotropin receptors, oocyte viability, and concentrations of steroids and insulin-like growth factors I and II in follicular fluid of lean and obese gilts Joumal of Animal Science 70 3149-3157 